\title{
PERBEDAAN GANGGUAN PENDENGARAN AKIBAT BISING ANTARA OPERATOR CCR PLTU DENGAN PLTGUDI PT PJB UP GRESIK
}

\author{
Irvan Prayogo, Noeroel Widajati \\ Departemen Keselamatan dan Kesehatan Kerja \\ Fakultas Kesehatan Masyarakat Universitas Airlangga \\ E-mail: irvanfkmunair@gmail.com
}

\begin{abstract}
The role of central control room (CCR) operator in Steam Power Plant (PLTU) or Gas and Steam Power Plant (PLTGU) of a work environment has high noise intensity with range (62.2-99.8 dBA). Noise resulting from the process of production of electrical energy by machinery such as power generation unit boiler/HRSG, turbine, generator, condenser and other supporting equipment can cause Noise Induced Hearing Loss (NIHL). Study with cross-sectional design aims to analyze the difference in Noise Induced Hearing Loss between shift operator CCR PLTU and PLTGU PT PJB UP Gresik. Research on samples taken with the technique of simple random sampling with the majority of respondents were $\geq 40$ years old, have a working periode $\geq 4$ years, have a work area with a level of intensity noise $>85 \mathrm{dBA}$, long exposure noise $\leq 1$ hour and good level of compliance of the use of ear protection in both of units. There was a difference of NIHL shift operator CCR PLTU and PLTGU. The number ofoperator who have experienced hearing loss due to noise on the shift operator CCR PLTU greater than PLTGU. Shift operator CCR PLTU and PLTGU are advised to obey and comply with safe working hours in areas with particular noise intensity has been set and the use of ear protection with right, also have to perform regular an audiometry exam tests so that the function of hearing of shift operator CCR could in monitor continuously.
\end{abstract}

Keywords: central control room operator, power plant, noise induced hearing loss

\begin{abstract}
ABSTRAK
Peran operator central control room (CCR) di unit pembangkitan PLTU maupun PLTGU tidak lepas dari lingkungan kerja yang mempunyai intensitas kebisingan tinggi dengan range (62,2-99,8 dBA). Bising yang dihasilkan dari proses produksi energi listrik oleh mesin atau peralatan unit pembangkitan seperti boiler/HRSG, turbin, generator, kondensor dan peralatan pendukung lain dapat menimbulkan gangguan pendengaran akibat bising (GPAB). Studi dengan desain cross-sectional ini bertujuan menganalisis perbedaan gangguan pendengaran akibat bising antara operator bergilir CCR PLTU dengan PLTGU di PT PJB UP Gresik. Sampel pada penelitian ini diambil menggunakan teknik simple random sampling dengan sebagian besar responden berusia $\geq 40$ tahun, memiliki masa kerja $\geq 4$ tahun, area kerja dengan tingkat intensitas bising $>85$ dBA, lama paparan bising $\leq 1$ jam dan penggunaan APT yang baik pada kedua unit. Terdapat perbedaan gangguan pendengaran akibat bising (GPAB) antara operator bergilir CCR PLTU dengan PLTGU di PT PJB UP Gresik. Jumlah operator yang mengalami gangguan pendengaran akibat bising (GPAB) pada operator bergilir CCR PLTU lebih banyak dibandingkan PLTGU. Operator bergilir central control room (CCR) PLTU disarankan untuk menaati dan mematuhi jam kerja aman di area dengan intensitas kebisingan tertentu yang telah ditetapkan dan menggunakan alat pelindung telinga (APT) dengan baik dan benar, serta melakukan tes audiometri secara periodik pada kedua unit agar fungsi pendengaran keduanya dapat dipantau secara kontinyu.
\end{abstract}

Kata kunci: operator central control room, unit pembangkit, gangguan pendengaran akibat bising

\section{PENDAHULUAN}

Menurut Adji (2015), dalam Info PJB, kebutuhan akan energi listrik saat ini berperan penting dalam berbagai bidang dan kegiatan manusia, mulai dari kegiatan rumah tangga, bisnis, industri, sosial, gedung kantor pemerintahan hingga penerangan jalan umum. Pemerintah sendiri melalui PT PLN (Persero) berkomitmen terus melanjutkan pembangunan pembangkit baru dengan total kapasitas 35.000 MW dalam lima tahun mendatang serta menyelesaikan $7.000 \mathrm{MW}$ on pipeline.

Dalam proses produksi energi kelistrikan nasional, PT PLN (Persero) mempunyai anak perusahaan yang bergerak di bidang unit pembangkitan energi listrik melalui berbagai jenis pembangkitan seperti PLTA, PLTU, PLTG, PLTGU, PLTD, PLTP, PLT Surya dan PLT Bayu di mana persentase terbesar penyumbang produksi paling 
banyak dihasilkan oleh jenis pembangkit PLTU dan PLTGU (PT PLN (Persero), 2013).

Data statistik yang dikeluarkan oleh PT PLN (Persero) tahun 2013 menunjukkan bahwa unit pembangkit (power plant) PLTU dan PLTGU merupakan unit penghasil energi listrik dengan persentase terbesar di antara jenis-jenis unit pembangkitan yang lain yakni dengan kontribusi $45,47 \%$ dan $25,77 \%$ dari total kapasitas terpasang baik di Jawa maupun luar Jawa (PT PLN (Persero), 2013).

PLTU merupakan unit pembangkit thermalyang menggunakan uap untuk menggerakkan turbin dengan memiliki peralatan utama yang terdiri atas boiler (ketel uap), turbin uap, generator, kondensor, pompa, pemanas air (water heater), pipa-pipa, kipas penekan udara (force draft fan), pemanas udara (air heater) dan kipas penghisap (induced draft fan), sedangkan pada PLTGU, prinsip kerjanya adalah dengan menggabungkan prinsip kerja PLTG dan PLTU yang mempunyai peralatan utama sistem PLTG meliputi kompresor, ruang bakar, turbin gas, dan generator, HRSG, turbin uap, kondensor, pemanas air (water heater), pipa-pipa dan pompa pengisi HRSG (Suliyantoko dan Sutomo, 2009).

Pada proses produksi energi listrik, pengoperasian seluruh peralatan pembangkit dilakukan oleh operator central control room(CCR). Operator central control room bertugas melakukan monitoring, controlling dan operating unit pembangkit dari ruang kontrol. Apabila terjadi permasalahan pada peralatan pembangkitan yang memerlukan tenaga ahli, maka operator central control room (CCR) mempunyai kewajiban melakukan pengamatan kondisi mesin atau peralatan dan mengatasi gangguan pada peralatan atau sistem.

Dalam prosesnya, unit pembangkit Pembangkit Listrik Tenaga Uap (PLTU) maupun Pembangkit Listrik Tenaga Gas dan Uap (PLTGU) beroperasi secara terus menerus (kontinyu) selama 24 jam per hari. Proses beroperasinya unit pembangkit PLTU dan PLTGU menimbulkan efek suara bising dengan intensitas tinggi dari peralatan atau mesin unit pembangkitan, baik dari peralatan atau mesin utama maupun penunjang.

Kebisingan menurut Permenakertras RI Nomor 12 Tahun 2011 adalah semua suara yang tidak dikehendaki yang bersumber dari alat-alat proses produksi dan atau alat-alat kerja yang pada tingkat tertentu dapat menimbulkan gangguan pendengaran. Pada unit Pembangkit Listrik Tenaga Uap (PLTU) misalnya, terdapat peralatan-peralatan utama unit pembangkit yang menimbulkan kebisingan dengan rata-rata intensitas kebisingannya mencapai 91,33 dBA. Disisi lain, pada unit PLTGU juga terdapat peralatan-peralatan utama yang menimbulkan kebisingan dengan rata-rata intensitas kebisingannya sebesar 88,93 dBA.

Menurut Bashiruddin dan Soetirto (2012), apabila pekerja melakukan pekerjaan di tempat dengan kebisingan tinggi dalam jangka waktu yang lama tanpa menggunakan APT (Alat Pelindung Telinga) dan memperhatikan waktu yang aman untuk bekerja, maka dapat menyebabkan gangguan pendengaran baik yang bersifat auditori maupun non auditori.

Menurut Harrington (2003), kebisingan juga dapat berpengaruh terhadap efek kesehatan selain fungsi pendengaran yakni pada beberapa bagian tubuh secara visceral seperti perubahan pada frekuensi detak jantung, perubahan tekanan darah, dan tingkat pengeluaran keringat.

Akan tetapi, pengaruh utama kebisingan bagi manusia adalah kerusakan indera pendengaran bagian dalam (auris interna) yang dapat menyebabkan beberapa gangguan pendengaran mulai dari menimbulkan reaksi adaptasi, peningkatan ambang dengar sementara (temporary threshold shift), peningkatan ambang dengar menetap (permanent threshold shift), dan tuli sensorineural (sensory neural hearing loss).

Sehingga, apabila akibat yang dapat ditimbulkan dari paparan kebisingan tersebut tidak segera dikendalikan, maka akan menimbulkan penyakit akibat kerja (PAK).

Dampak yang dapat ditimbulkan oleh penyakit akibat kerja yakni akan membuat menurunnya performansi dan produktivitas pekerja sehingga pencapaian perusahaan yang dibebankan tidak tercapai, serta merugikan perusahaan dan pekerja itu sendiri.

Penelitian ini bertujuan menganalisis perbedaan gangguan pendengaran akibat bising antara operator bergilir central control room(CCR) pembangkit listrik tenaga uap (PLTU) dengan pembangkit listrik tenaga gas uap (PLTGU) di PT Pembangkitan Jawa Bali Unit Pembangkitan Gresik.

\section{METODE}

Penelitian ini merupakan penelitian observasional analitik, karena data diperoleh dengan tidak memberikan perlakuan atau interaksi pada 
sampel yang diteliti dan bertujuan mengetahui perbedaan gangguan pendengaran akibat bising pada dua sampel bebas. Ditinjau dari segi waktu, penelitian ini bersifat crossectional karena dilakukan secara serentak dalam satu waktu tertentu (Notoatmodjo, 2012).

Populasi dalam penelitian ini adalah seluruh operator bergilir central control room unit PLTU dan PLTGU yang berjumlah 46 orang yang terdiri atas 31 operator bergilir central control room PLTU dan 15 operator bergilir central control room PLTGU. Sampel yang diambil dalam penelitian ini memiliki kriteria inklusi antara lain telah bekerja paling sedikit selama 1 tahun dan bersedia berpartisipasi dalam penelitian dengan menandatangani lembar persetujuan sedangkan untuk kriteria ekslusi meliputi sedang menggunakan obat ototoksik. Sampel diambil menggunakan teknik simple random sampling dengan sampel terpilih sebanyak 41 orang dan setelah dilakukan perhitungan proporsi, didapatkan 28 orang sampel dari operator bergilir central control room PLTU dan 13 orang sampel dari operator bergilir central control room PLTGU.

Penelitian ini dilaksanakan di Unit Central Control Room PLTU dan PLTGU PT PJB Unit Pembangkitan Gresik pada tanggal 03 Mei sampai 10 Juni 2015.

Variabel dalam penelitian ini meliputiusia, masa kerja, pemenuhan menggunakan APT, lama paparan kebisinan, tingkat intensitas kebisingan dan gangguan pendengaran akibat bising. Komponen penelitian ini dihimpun melalui kuesioner, kegiatan observasi dan menggunakan data sekunder berupa hasil Medical Check Up (MCU) pemeriksaan audiometri operator bergilir central control room PLTU dan PLTGU.

Data yang berhasil dihimpun selanjutnya diolah secara univariat dan bivariat. Analisis univariat digunakan untuk mendiskripsikan masing-masing variabel yang diteliti, sedangkan analisis bivariat digunakan untuk melihat perbedaan antara dua variabel sampel bebas. Hasil data analisis bivariat disajikan dalam bentuk tabulasi silang.

Uji analisis data bivariat yang digunakan adalah tabulasi silang (kontingensi) $2 \times 2$ dengan tingkat kemaknaan $\alpha$ (alpha) sebesar 0,05 . Sedangkan untuk mengetahui perbedaan antara dua sampel bebas, dilihat melalui pembacaan hasil Chi-Square Yate's Correction for Continuity atau Fisher's Exact. Pembacaan hasil Chi-Square Yate's Correction for Continuity dilakukan apabila setiap sel tidak ada nilai yang $<1$, dan tidak boleh lebih dari $20 \%$ jumlah sel yang ada mempunyai nilai harapan (expected) $<$ 5. Apabila syarat ini tidak terpenuhi, maka hasil pembacaan menggunakan Fisher's Exact.

\section{HASIL}

\section{Gambaran Umum Tempat Penelitian}

PT PJB Unit Pembangkitan Gresik merupakan anak perusahaan PT PLN (Persero) Holding Company yang bergerak di bidang energi listrik dan kesiapan operasi pembangkit. PT PJB Unit Pembangkitan Gresik mempunyai 3 unit mesin pembangkitan dengan total kapasitas terpasang sebesar 2.218,2 MW yang terdiri atas Pembangkit Listrik Tenaga Gas (PLTG) yang mempunyai kapasitas 40,2 MW, Pembangkit Listrik Tenaga Uap (PLTU) yang mempunyai kapasitas 600,0 MW dan Pembangkit Listrik Tenaga Gas Uap (PLTGU) dengan kapasitas 1578,0 MW. PT PJB sendiri mempunyai mekanisme jual beli dengan penyampaian produk ke pelanggan (P3B) dikirim langsung melalui Saluran Udara Tegangan Tinggi $150 \mathrm{kV}$ dan Tegangan Ekstra Tinggi $500 \mathrm{kV}$ dalam sistem Jawa, Madura dan Bali.

Dalam proses produksi energi kelistrikannya, operator central control room (CCR) mempunyai peran dan tanggung jawab yang besar, di mana job description yang mereka miliki terbagi atas tujuan jabatan, tugas dan tanggung jawab serta hubungan kerja dengan internal maupun eksternal perusahaan.

Tujuan jabatan operator central control room PLTU atau PLTGU adalah mengoperasikan, memonitor, mengendalikan, dan mengevaluasi operasi unit pembangkit untuk menjaga kualitas. Efisiensi, dan kestabilan sistem operasi sehingga mampu berfungsi dengan keandalan optimal, sedangkan tugas dan tanggung jawab operator central control room adalah mengkoordinir tugas operator lokal dalam rangka mengoperasikan peralatan utama dan peralatan bantu unit pembangkitan, mengevaluasi pengujian-pengujian operasi peralatan sesuai SOP, membuat laporan kegiatan produksi secara periodik, melaksanakan tugas yang di delegasikan oleh Supervisor Senior, membuat atau mereview SOP atau IK dan melakukan entry data pada program Navitas, MIMS, E-Logsheet dan Ikhtisar perusahaan. Disisi lain, operator mempunyai hubungan kerja internal untuk selalu berkoordinasi dengan operator central control room (CCR) PLTU maupun PLTGU tiap unit terkait pemakaian make up water dan bahan bakar gas, 
bidang pemeliharaan dalam pelaksanaan pekerjaan rutin, dan bidang laboratorium untuk pengawasan mutu air dan bahan bakar di unit pembangkitan, sedangkan hubungan eksternal mempunyai maksud untuk selalu berkoordinasi dengan PT PLN (Persero) Penyaluran dan Pusat Pengaturan Beban Jawa Bali (P3B) untuk pengaturan beban unit secara berkala.

\section{Usia}

Responden dalam penelitian ini terbagi menjadi dua kategori menurut unit kerjanya, dengan rincian sebanyak $28(68,3 \%)$ responden termasuk dalam unit central control room PLTU dan sisanya sebanyak 13 $(31,7 \%)$ responden termasuk dalam unit central control room PLTGU.

Tabel berikut menggambarkan distribusi usiapada operator bergilir central control room PLTU dan PLTGU di PT PJB Unit Pembangkitan Gresik.

Tabel 1. Distribusi Usia pada Operator Bergilir Central Control Room PLTU dan PLTGU di PT PJB Unit Pembangkitan Gresik 2015

\begin{tabular}{|c|c|c|c|}
\hline \multirow{3}{*}{$\begin{array}{c}\text { Usia } \\
\text { Responden }\end{array}$} & \multicolumn{2}{|c|}{ Frekuensi } & \multirow[b]{2}{*}{ Total } \\
\hline & $\begin{array}{c}\text { Operator } \\
\text { CCR PLTU }\end{array}$ & $\begin{array}{c}\text { Operator } \\
\text { CCR PLTGU }\end{array}$ & \\
\hline & n $(\%)$ & n $(\%)$ & n (\%) \\
\hline$\geq 40$ tahun & $25(61,0)$ & $12(29,3)$ & $37(90,2)$ \\
\hline$<40$ tahun & $3(7,3)$ & $1(2,4)$ & $4(9,8)$ \\
\hline Total & $28(68,3)$ & $13(31,7)$ & $41(100)$ \\
\hline
\end{tabular}

Berdasarkan Tabel 1 dapat diketahui bahwa sebagian besar usia responden pada operator bergilir central control room PLTU dan PLTGU tergolong $\geq 40$ tahun, dengan persentase keduanya sebesar $90,2 \%$ (37 orang) yang terbagi atas $61,0 \%$ (25 orang) dari Unit CCR PLTU dan 29,3\% (12 orang) dari Unit CCR PLTGU.

\section{Masa Kerja}

Tabel 2 menggambarkan distribusi masa kerja pada operator bergilir Central Control Room PLTU dan PLTGU di PT PJB Unit pembangkitan Gresik.

Berdasarkan Tabel 2 dapat diketahui bahwa masa kerja operator bergilir central control room baik dari PLTU maupun PLTGU tergolong memiliki masa kerja $\geq 4$ tahun denga persentase keduanya sebesar $82,9 \%$ (34 orang) yang terbagi atas $61,0 \%$ (25 orang) dari Unit CCR PLTU dan $22,0 \%$ (9 orang) dari Unit CCR PLTGU.
Tabel 2. Distribusi Masa Kerja pada Operator Bergilir Central Control Room PLTU dan PLTGU di PT PJB Unit Pembangkitan Gresik 2015

\begin{tabular}{|c|c|c|c|}
\hline \multirow{3}{*}{ Masa Kerja } & \multicolumn{2}{|c|}{ Frekuensi } & \multirow[b]{2}{*}{ Total } \\
\hline & $\begin{array}{c}\text { Operator } \\
\text { CCR PLTU }\end{array}$ & $\begin{array}{c}\text { Operator } \\
\text { CCR PLTGU }\end{array}$ & \\
\hline & n (\%) & n $(\%)$ & n $(\%)$ \\
\hline$\geq 4$ tahun & $25(61,0)$ & $9(22,0)$ & $34(82,9)$ \\
\hline$<4$ tahun & $3(7,3)$ & $4(9,7)$ & $7(17,1)$ \\
\hline Total & $28(68,3)$ & $13(31,7)$ & $41(100)$ \\
\hline
\end{tabular}

\section{Tingkat Intensitas Kebisingan}

Tabel berikut menggambarkan tingkat intensitas kebisingan di lingkungan kerja operator bergilir central control room PLTU dan PLTGU di PT PJB Unit Pembangkitan Gresik.

Tabel 3. Tingkat Intensitas Kebisingan di Lingkungan Kerja Operator Bergilir Central Control Room PLTU dan PLTGU di PT PJB Unit Pembangkitan Gresik 2015

\begin{tabular}{llc}
\hline Unit & \multicolumn{1}{c}{ Lokasi Kerja } & $\begin{array}{c}\text { Tingkat } \\
\text { Intensitas Bising } \\
\text { (dBA) }\end{array}$ \\
\hline PLTU & GF Unit 1,2 BFP & 95,5 \\
PLTU & MB Lt.2 Unit 1,2 & 93,3 \\
PLTU & CCR Unit 1,2 & 72,1 \\
PLTU & MB Lt.3 Unit 1,2 & 94,0 \\
PLTU & Boiler Unit 1 & 89,4 \\
PLTU & Boiler Unit 2 & 92,8 \\
PLTU & FDF Unit 1 & 99,8 \\
PLTU & GF Unit 3,4 BFP & 92,4 \\
PLTU & MB Lt.2 Unit 3,4 & 95,4 \\
PLTU & CCR Unit 3,4 & 71,2 \\
PLTU & MB Lt.3 Unit 3,4 & 96,1 \\
PLTU & Boiler Unit 3 & 92,4 \\
PLTU & Boiler Unit 4 & 90,0 \\
PLTU & FDF Unit 3 & 94,5 \\
PLTGU & GF ST 1 & 95,1 \\
PLTGU & MB Lt. 2 ST 1 & 92,2 \\
PLTGU & CCR PLTGU A,B & 62,2 \\
PLTGU & MB Lt.3 ST 1-2 & 92,7 \\
PLTGU & HRSG Unit 1 & 94,7 \\
PLTGU & HRSG Unit 2 & 93,5 \\
PLTGU & Generator Turbin 1 & 95,8 \\
PLTGU & GF ST 2 & 91,8 \\
PLTGU & CCR PLTGU C,D & 62,2 \\
PLTGU & MB Lt.3 ST 2-3 & 98,0 \\
PLTGU & HRSG Unit 3 & 91,6 \\
PLTGU & HRSG Unit 4 & 84,5 \\
PLTGU & Generator Turbin 3 & 92,6 \\
\hline & &
\end{tabular}


Berdasarkan Tabel 3 menunjukkan tingkat intensitas kebisingan di lingkungan kerja operator bergilir central control room (CCR) PLTU dan PLTGU, Unit CCR PLTU mempunyai lingkungan kerja dengan intensitas terendah sebesar 72,1 dBA dan tertinggi sebesar 99,8 dBA. Sedangkan Unit CCR PLTGU mempunyai lingkungan kerja dengan intensitas kebisingan terendah sebesar 62,2 dBA dan tertinggi sebesar 98,0 dBA. Jika di rata-rata pada Unit CCR PLTU mempunyai lingkungan kerja dengan intensitas kebisingan sebesar 91,33 dBA, sedangkan Unit CCR PLTGU mempunyai lingkungan kerja dengan intensitas kebisingan sebesar 88,93 dBA.

\section{Lama Paparan Bising}

Tabel berikut menggambarkan lama paparan kebisingan pada operator bergilir central control room PLTU dan PLTGU di PT PJB Unit pembangkitan Gresik.

Tabel 4. Distribusi Lama Paparan Kebisingan pada Operator Bergilir Central Control Room PLTU dan PLTGU di PT PJB Unit Pembangkitan Gresik 2015

\begin{tabular}{|c|c|c|c|}
\hline \multirow{3}{*}{$\begin{array}{c}\text { Lama } \\
\text { Paparan } \\
\text { Bising }\end{array}$} & \multicolumn{2}{|c|}{ Frekuensi } & \multirow[b]{2}{*}{ Total } \\
\hline & $\begin{array}{c}\text { Operator } \\
\text { CCR PLTU }\end{array}$ & $\begin{array}{c}\text { Operator CCR } \\
\text { PLTGU }\end{array}$ & \\
\hline & n $(\%)$ & n (\%) & n (\%) \\
\hline$\leq 1$ jam & $21(51,2)$ & $13(31,7)$ & $34(82,9)$ \\
\hline$>1 \mathrm{jam}$ & $7(17,1)$ & $0(0,0)$ & $7(17,1)$ \\
\hline Total & $28(68,3)$ & $13(31,7)$ & $41(100)$ \\
\hline
\end{tabular}

Berdasarkan Tabel 4 dapat diketahui bahwa lama paparan operator bergilir central control room baik dari unit kerja PLTU maupun PLTGU tergolong memiliki lama paparan bising $\leq 1$ tahun dengan persentase keduanya sebesar $82,9 \%$ (34 orang), terbagi atas $51,2 \%$ (21 orang) dari unit central control room (CCR) pembangkit listrik tenaga uap (PLTU) dan 31,7\% (13 orang) dari unit central control room (CCR) pembangkit listrik tenaga gas dan uap (PLTGU) di PT Pembangkit Jawa Bali Unit Pembangkitan Gresik.

\section{Penggunaan APT (Alat Pelindung Telinga)}

Tabel berikut menggambarkan tingkat pemenuhan penggunaan APT (Alat Pelindung Telinga) pada operator bergilir central control room PLTU dan PLTGU di PT Pembangkit Jawa Bali Unit Pembangkitan Gresik.
Tabel 5. Distribusi Penggunaan APT pada Operator Bergilir Central Control Room PLTU dan PLTGU di PT PJB Unit Pembangkitan Gresik 2015

\begin{tabular}{|c|c|c|c|}
\hline \multirow{3}{*}{$\begin{array}{c}\text { Penggunaan } \\
\text { APT }\end{array}$} & \multicolumn{2}{|c|}{ Frekuensi } & \multirow[b]{2}{*}{ Total } \\
\hline & $\begin{array}{c}\text { Operator } \\
\text { CCR PLTU }\end{array}$ & $\begin{array}{c}\text { Operator } \\
\text { CCR PLTGU }\end{array}$ & \\
\hline & n $(\%)$ & n $(\%)$ & n (\%) \\
\hline Baik & $15(36,6)$ & $12(29,3)$ & $27(65,9)$ \\
\hline Buruk & $13(31,7)$ & $1(2,4)$ & $14(34,1)$ \\
\hline Total & $28(68,3)$ & $13(31,7)$ & $41(100)$ \\
\hline
\end{tabular}

Berdasarkan Tabel 5 dapat diketahui bahwa sebagian besar operator bergilir central control room (CCR) PLTU dan PLTGU tergolong memiliki tingkat pemenuhan penggunaan alat pelindung telinga (APT) yang baik dengan persentase keduanya sebesar $65,9 \%$ (27 orang) yang terbagi atas $36,6 \%$ (15 orang) dari unit central control room (CCR) unit pembangkit listrik tenaga uap (PLTU) dan 29,3\% (12 orang) dari unit central control room (CCR) unit pembangkit listrik tenaga gas uap (PLTGU).

\section{Gangguan Pendengaran Akibat Bising}

Tabel 6 menggambarkan gangguan pendengaran akibat bising (GPAB) pada operator bergilir central control room Pembangkit Listrik Tenaga Uap (PLTU) dan Pembangkit Listrik Tenaga Gas Uap (PLTGU) di PT Pembangkit Jawa Bali Unit Pembangkitan Gresik.

Berdasarkan Tabel 6 di bawah dapat diketahui bahwa sebagian besar operator bergilir central control room baik dari unit pembangkit listrik tenaga uap (PLTU) dan pembangkit listrik tenaga gas uap (PLTGU) tidak mengalami gangguan pendengaran akibat bising (GPAB) dengan persentase keduanya sebesar $80,5 \%$ (33 orang), terbagi atas 48,8\% (20 orang) dari unit central control room (CCR) unit

Tabel 6. Distribusi Gangguan Pendengaran Akibat Bising (GPAB) pada Operator Bergilir Central Control Room PLTU dan PLTGU di PT PJB Unit Pembangkitan Gresik 2015

\begin{tabular}{|c|c|c|c|}
\hline \multirow{3}{*}{$\begin{array}{c}\text { Gangguan } \\
\text { Pendengaran } \\
\text { Akibat } \\
\text { Bising }\end{array}$} & \multicolumn{2}{|c|}{ Frekuensi } & \multirow[b]{2}{*}{ Total } \\
\hline & $\begin{array}{c}\text { Operator } \\
\text { CCR PLTU }\end{array}$ & $\begin{array}{c}\text { Operator } \\
\text { CCR PLTGU }\end{array}$ & \\
\hline & n (\%) & $\mathrm{n}(\%)$ & n (\%) \\
\hline $\mathrm{Ya}$ & $8(19,5)$ & $0(0,0)$ & $8(19,5)$ \\
\hline Tidak & $20(48,8)$ & $13(31,7)$ & $33(80,5)$ \\
\hline Total & $28(68,3)$ & $13(31,7)$ & $41(100)$ \\
\hline
\end{tabular}


pembangkit listrik tenaga uap (PLTU) dan 31,7\% (13 orang) dari unit central control room (CCR) unit pembangkit listrik tenaga gas uap (PLTGU) PT Pembangkitan Jawa-Bali Unit Pembangkitan Gresik.

\section{Perbedaan Gangguan Pendengaran Akibat Bising Antara Operator Bergilir Central Control Room PLTU dan PLTGU}

Analisis perbedaan gangguan pendengaran akibat bising (GPAB) antara operator bergilir central control room Pembangkit Listrik Tenaga Uap (PLTU) dan Pembangkit Listrik Tenaga Gas dan Uao (PLTGU) di PT Pembangkitan Jawa Bali Unit Pembangkitan Gresik diuji secara statistik menggunakan uji beda Tabulasi Silang (Kontingensi) $2 \times 2$, karena pada hasil uji statistik menunjukkan terdapat sel yang mempunyai nilai expected $<5$, maka dilakukan pembacaan hasil pada Fisher's Exact.

Hasil analisis statistik diperoleh nilai signifikansi $0,040<\alpha(\alpha=0,05)$ yang berarti terdapat perbedaan yang signifikan gangguan pendengaran akibat bising (GPAB) antara operator bergilir central control room (CCR) PLTU dan PLTGU di PT Pembangkit Jawa Bali Unit Pembangkitan Gresik.

\section{PEMBAHASAN}

\section{Usia}

Sebanyak $21(61,0 \%)$ operator bergilir dari unit central control room (CCR) PLTU dan 12 (29,3\%) operator bergilir dari unit central control room (CCR) PLTGU tergolong memiliki usia lebih dari sama dengan 40 tahun.

Usia merupakan salah satu faktor yang berpengaruh terhadap terjadinya gangguan pendengaran akibat bising (GPAB) yang ditimbulkan di tempat kerja bising. Semakin bertambah usia seseorang, maka akan semakin menurun nilai ambang dengarnya dan akan berdampak pada gangguan pendengaran baik yang bersifat auditorial maupun non auditorial (Tambunan, 2005).

Disisi lain, menurut Djojodibroto (1999), menyatakan asumsi kenaikan ambang dengar yang berkaitan dengan gangguan pendengaran akibat bising dimulai dari usia 40 tahun. Penelitian yang dilakukan oleh Rauch (2011) dalam Novita (2013), menunjukkan gangguan pendengaran akibat kebisingan dapat ditemukan pada semua kelompok usia, umumnya terjadi pada rentang usia antara 40 sampai 50 tahun. Sehingga dapat dikatakan bahwa seiring bertambahnya usia dan terjadinya paparan bising di tempat kerja merupakan faktor terjadinya gangguan pendengaran.

Tekanan kebisingan yang diterima pekerja dengan intensitas tinggi secara kontinyu dalam jangka waktu panjang akan menyebabkan sel rambut yang mati meskipun seseorang tersebut masih berusia muda. Disisi lain, ketulian seseorang dipengaruhi juga oleh lama paparan kebisingan yang diterima walaupun usianya masih muda (Irwandi, 2008).

\section{Masa Kerja}

Hasil penelitian menunjukkan sebanyak 25 responden dengan persentase $61,0 \%$ dari unit central control room (CCR) PLTU dan 9 responden dengan persentase $22,0 \%$ dari unit central control room (CCR) PLTGU tergolong memiliki masa kerja di unit central control room (CCR) PLTU atau PLTGU sebagai operator selama lebih dari sama dengan 4 tahun.

Masa kerja seseorang yang bekerja di tempat kerja bising dengan tingkat intensitas kebisingan melebihi Nilai Ambang Batas (NAB) yang dipersyaratkan dalam waktu kerja aman harian (85 dBA) memiliki pengaruh dan hubungan yang sangat kuat dengan terjadinya gangguan pendengaran, diantaranya adalah gangguan sensori neural (Sensory Neural Hearing Loss/SNHL) dan gangguan campuran (Mixed Hearing Loss/MHL) (European Agency for Safety and Health at Work, 2008).

Menurut Soetirto (1997), penurunan pendengaran atau gangguan masalah pendengaran pada pekerja yang terpajan bising biasanya terjadi setelah masa kerja 5 tahun, dengan tidak menutup kemungkinan dapat terjadi kurang dari waktu 5 tahun tersebut apabila pekerja terpapar bising dengan intensitas tinggi yang melebihi batas waktu aman bekerja di tempat tersebut.

Disisi lain, penelitian yang dilakukan oleh Rafika (2015) menyatakan bahwa masa kerja tidak akan menjadi faktor penyebab atau terjadinya gangguan pendengaran jika pekerja tidak mengalami paparan bising.

\section{Tingkat Intensitas Kebisingan}

Operator central control room (CCR) yang bertugas baik di unit PLTU maupun PLTGU harus mengetahui secara komprehensif atau menyeluruh 
setiap komponen peralatan utama dan peralatan pendukung unit pembangkitan.

Ditinjau dari sifat, spektrum frekuensi dan pengaruhnya terhadap manusia (pekerja), intensitas kebisingan yang berada dalam area kerja unit central control room (CCR) PLTU dan PLTGU termasuk dalam intensitas bising yang bersifat kontinyu atau terus menerus.

Pada intensitas kebisingan yang diukur berdasarkan lingkup area kerja dominan yang dilakukan oleh operator bergilir central control room (CCR) PLTU dan PLTGU didapatkan bahwa pada unit area kerja central control room (CCR) PLTU mempunyai rerata intensitas kebisingan 91,33 dBA, sedangkan pada unit area kerja central control room (CCR) PLTGU mempunyai rerata intensitas kebisingan 88,93 dBA.

Nilai Ambang Batas (NAB) yang diperkenankan mengacu pada Peraturan Menteri Tenaga Kerja dan Transmigrasi No. PER.13/MEN/X/2011 tentang Nilai Ambang Batas Faktor Fisika dan Faktor Kimia di Tempat Kerja, ditetapkan sebesar 85 dBA selama 8 jam per hari dan 40 jam per minggu. Pada kasusnya jika unit PLTU maupun PLTGU mengalami trouble atau gangguan dari peralatan utama dan atau peralatan pendukung pembangkitan, diperlukan waktu hingga berjam-jam untuk mengatasi permasalahan tersebut. Dengan rerata intensitas kebisingan yang lebih dari $85 \mathrm{dBA}$ di hampir semua titik area lingkup kerja operator bergilir central control room (CCR) PLTU dan PLTGU, dapat dipastikan bahwa hal tersebut sangat berpengaruh terhadap gangguan pendengaran.

\section{Lama Paparan Bising}

Hasil penelitian menunjukkan terkait dengan lama paparan bising pada operator bergilir central control room(CCR) PLTU dan PLTGU tergolong memiliki lama paparan bising kurang dari sama dengan 1 jam dengan persentase keduanya sebesar $82,9 \%$ (34 orang).

Area lingkungan kerja unit central control room(CCR) PLTU dan PLTGU yang mempunyai intensitas kebisingan yang tinggi yakni 89,3-91,3 dBA ( $>85 \mathrm{dBA})$, jika dilihat dari waktu aman pekerja bekerja di area tersebut, maka pekerja tidak boleh terpapar kebisingan lebih dari 2 jam per hari. Di sisi lain, jika terdapat gangguan yang menyebabkan unit trouble seperti pada peralatan utama atau peralatan pendukung unit pembangkitan, terkadang memakan waktu hingga harian. Efek kebisingan akan sebanding dengan lama pekerja terpapar bising tersebut (European Agency For Safety and Health at Work, 2008).

Penelitian yang dilakukan oleh Turmaningsih (2010), menyatakan bahwa semakin bertambang tingkat lama paparan bising, maka semakin meningkat nilai ambang dengar seseorang. Peningkatan nilai ambang dengar pada setiap pertambahan lama paparan bising membuktikan bahwa penurunan daya dengar merupakan akibat dari pertambahan lama paparan.

Gangguan pendengaran akibat bising berhubungan dengan lama paparan bising dalam jangka waktu tertentu. Responden yang bekerja di area kerja dengan intensitas kebisingan yang tinggi secara kontinyu selama bertahun-tahun selama bekerja di unit tersebut dapat mengalami gangguan pendengaran akibat bising yang menyerang telinga dalam (auris interna).

Dengan kata lain, terjadinya gangguan pendengaran akibat bising tersebut baru disadari setelah beberapa tahun bekerja. Sehingga dapat diambil kesimpulan bahwa terjadinya gangguan pendengaran akibat bising juga disebabkan oleh lama paparan bising di tempat kerja bising.

\section{Pemenuhan Penggunaan Alat Pelindung Telinga (APT)}

Sebanyak $15(36,6 \%)$ responden dari unit central control room (CCR) PLTU dan 12 (29,3\%) responden dari unit central control room (CCR) PLTGU tergolong memiliki tingkat pemenuhan penggunaan alat pelindung telinga (APT) yang baik. Akan tetapi, $13(31,7 \%)$ dari 28 responden unit central control room (CCR) PLTU tergolong memiliki tingkat pemenuhan penggunaan alat pelindung telinga (APT) yang buruk.

Sosialisasi penggunaan atau pemakaian alat pelindung telinga (APT) di PT PJB Unit Pembangkitan Gresik sudah disampaikan oleh crewK3 kepada supervisor tiap unit kerja (Unit Central Control Room PLTU atau PLTGU) dalam rapat rutin Panitia Pembina Keselamatan dan Kesehatan Kerja (P2K3) perusahaan. Selanjutnya operator bergilir central control room hanya mendapat penjelasan tentang pentingnya penggunaan alat pelindung telinga (APT) dari Supervisor Senior yang memimpin unit (Unit Central Control Room PLTU atau PLTGU), sehingga apabila peran Supervisor Senior dalam sosialisasi ke bawahannya (operator bergilir central control room PLTU atau PLTGU) tidak berjalan dengan baik, maka upaya pengendalian kebisingan yang dapat menimbulkan 
gangguan pendengaran akibat bising menjadi siasia.

Seperti diketahui bahwa APT dalam penggunaannya sebagai upaya pengendalian terhadap efek kebisingan di tempat kerja dapat memberikan Noise Reduction Rate (NRR) dengan besar nilai tertentu agar pekerja tetap aman bekerja di tempat kerja bising dengan intensitas tertentu.

Berdasarkan teori, penggunaan APT merupakan salah satu tindakan pengendalian kebisingan di tempat kerja untuk mengurangi paparan kebisingan yang berlebih agar tidak berdampak buruk bagi kesehatan, khususnya berkaitan dengan fungsi pendengaran pekerja yang terpapar bising (Siswanto, 1998).

Di samping itu, menurut Suma'mur (2009) menyatakan bahwa APT yang disediakan sebagai langkah pengendalian kebisingan di tempat kerja harus memenuhi persyaratan diantaranya nyaman dipakai, tidak mengganggu dalam bekerja dan memberikan perlindungan efektif terhadap jenis bahaya.

\section{Gangguan Pendengaran Akibat Bising}

Hasil penelitian menunjukkan sebanyak 20 responden dengan persentase $48,8 \%$ dari unit central control room (CCR) PLTU dan sebanyak 13 responden dengan persentase $31,7 \%$ dari unit central control room (CCR) PLTGU tergolong tidak mengalami gangguan pendengaran akibat bising. Akan tetapi, pada unit central control room (CCR) PLTU terdapat sebanyak 8 responden dengan persentase $19,5 \%$ yang telah mengalami gangguan pendengaran akibat bising.

Proporsi operator bergilir central control room (CCR) pembangkit listrik tenaga uap (PLTU) yang mengalami gangguan pendengaran akibat bising dengan persentase sebesar $28,6 \%$ atau hampir sepertiganya. Hal ini berbanding terbalik dengan proporsi operator bergilir central control room (CCR) pembangkit listrik tenaga gas uap (PLTGU) yang mengalami gangguan pendengaran akibat bising dengan persentase sebesar $0,0 \%$.

Menurut Bashiruddin dan Soetirto (2012) banyak hal yang dapat seseorang menderita gangguan pendengaran akibat bising, seperti terpajan kebisingan dengan intensitas bising yang tinggi, lama pajanan kebisingan, dan pengobatan yang bersifat racun seperti obat ototoksik. Akibat penggunaan obat-obat yang bersifat ototksik sendiri akan dapat menimbulkan terjadinya gangguan fungsional pada telinga dalam yang disebabkan telah terjadinya perubahan struktur anatomi pada organ telinga dalam, jenis-jenis obat ototoksik tersebut diantaranya aminoglikosida, eritromisin, loop diuretics, obat anti inflamasi, obat anti malaria, obat anti tumor dan obat tetes telinga.

\section{Perbedaan Gangguan Pendengaran Akibat Bising Antara Operator Bergilir Central Control Room PLTU dan PLTGU}

Hasil uji statistik dengan menggunakan Tabulasi Silang (Kontingensi) $2 \times 2$ dengan pembacaan hasil uji pada Fisher Exact menunjukkan adanya perbedaan gangguan pendengaran akibat bising antara operator bergilir central control room (CCR) PLTU dan PLTGU dengan nilai signifikansi 0,040 $(\mathrm{p}<0,05)$.

Menurut hasil analisis data terkait dengan adanya perbedaan gangguan pendengaran akibat bising antara operator bergilir central control room (CCR) PLTU dan pembangkit listrik tenaga gas uap (PLTGU) terdapat beberapa faktor yang menimbulkan perbedaan di antara kedua unit tersebut, diantaranya adalah usia, masa kerja, tingkat pajanan kebisingan, lama paparan kebisingan, pemenuhan penggunaan APT, infeksi telinga, lubang pada gendang telinga, dan tumor (Bashiruddin dan Soetirto, 2012). Di mana semua operator bergilir central control room yang mengalami gangguan pendengaran akibat bising berasal daru unit central control room PLTU dengan jumlah responden yang mengalami gangguan sebanyak 8 responden $(19,5 \%)$.

Hasil analisis data terkait dengan tingkat pajanan kebisingan, operator yang bekerja di unit central control room PLTU memiliki area kerja dengan rerata kebisingan sebesar 91,33 dBA sedangkan pada area kerja unit central control room PLTGU mempunyai rerata intensitas kebisingan sebesar 88,93 dBA. Terdapat selisih 2,4 dBA pada exchange rate, namun terkait dengan waktu aman bekerja, selisih 2,4 dBA ini sangat penting mengacu pada Peraturan Menteri Tenaga Kerja dan Transmigrasi Nomor 13 Tahun 2011 tentang Nilai Ambang Batas Faktor Fisika dan Faktor Kimia di Tempat Kerja, waktu aman yang diperbolehkan operator bergilir central control room terpapar kebisingan pada intensitas kebisingan sebesar 91,33 dBA adalah kurang lebih selama 2 jam per hari, sedangkan waktu aman yang diperbolehkan operator central control room terpapar kebisingan pada intensitas kebisingan sebesar 88,93 adalah sekitar 4 jam per hari. Dari hasil analisis tersebut dapat disimpulkan bahwa 
operator central control room (CCR) pembangkit listrik tenaga uap (PLTU) mempunyai waktu aman bekerja yang relatif lebih singkat dari pada operator central control room (CCR) pembangkit listrik tenaga gas uap (PLTGU), sehingga proporsi risiko terjadinya gangguan pendengaran akibat bising juga semakin besar.

Ditinjau dari segi lama paparan kebisingan, menurut hasil penelitian menunjukkan bahwa sebagian besar operator bergilir central control room (CCR) pembangkit listrik tenaga uap (PLTU) mempunyai waktu paparan bising lebih lama dari pada operator bergilir central control room (CCR) pembangkit listrik tenaga gas uap (PLTGU), di mana 7 responden $(17,1 \%)$ dari unit central control room (CCR) pembangkit listrik tenaga uap (PLTU) diantaranya memiliki lama paparan bising di tempat kerja bising lebih dari 1 jam per hari. Jika dikaitkan dengan waktu aman bekerja dengan rerata intensitas kebisingan lingkungan kerja unit central control room (CCR) pembangkit listrik tenaga uap (PLTU) sebesar 91,33 dBA, maka dapat dikatakan bahwa operator bergilir central control room (CCR) pembangkit listrik tenaga uap (PLTU) mempunyai risiko yang lebih tinggi terkena gangguan pendengaran akibat bising dari pada operator central control room (CCR) pembangkit listrik tenaga gas uap (PLTGU).

Kemudian terkait dengan tingkat pemenuhan penggunaan APT (Alat Pelindung Telinga), operator bergilir central control room (CCR) pembangkit listrik tenaga uap (PLTU) memiliki tingkat pemenuhan yang buruk di bandingakan dengan operator bergilir central control room (CCR) pembangkit listrik tenaga gas uap (PLTGU). Penyebab timbulnya pemenuhan penggunaan APT yang buruk dapat diakibatkan oleh berbagai hal, diantaranya supervisi dari Supervisor Senior yang buruk, ketidaknyamanan APT yang disediakan oleh perusahaan, Nilai Noise Reduction Rate (NRR) yang tidak sesuai, dan lain sebagainya. Menurut Standards (2002), APT (Alat Pelindung Telinga) merupakan penghalang akustik (accoustic barrier) yang dapat mengurangi jumlah energi suara yang melewati lubang telinga menuju reseptor di dalam telinga. Sehingga jika tingkat pemenuhan penggunaan APT buruk, maka jumlah energi suara yang melewati lubang telinga menuju reseptor di telinga dalam akan semakin besar dan dapat menimbulkan gangguan pendengaran akibat bising.
Penelitian yang dilakukan oleh Dibyaguna (2015) terkait dengan intensitas kebisingan dan nilai ambang dengar menunjukkan hasil perhitungan Daily Noise Dose (DND) responden yang bekerja di area lingkungan kerja unit Pembangkit Listrik Tenaga Uap (PLTU) berkisar antara 1 hingga 5,8 yang berarti melebihi batas normal Daily Noise Dose (DND) normal $(\leq 1)$.

Umumnya, penurunan daya pendengaran akibat kebisingan terjadi secara perlahan dalam waktu yang cukup lama dan terkadang tanpa disadari. Besarnya risiko penurunan daya pendengaran akibat kebisingan ini berbanding lurus dengan besarnya paparan intensitas kebisingan dan lama pemaparannya, sehingga mengurangi faktor-faktor risiko tersebut adalah salah satu upaya untuk mengurangi risiko penurunan daya pendengaran tersebut (Sasongko, dkk 2000).

\section{SIMPULAN}

Terdapat perbedaan gangguan pendengaran akibat bising antara operator bergilir central control room (CCR) pembangkit listrik tenaga uap (PLTU) dengan pembangkit listrik tenaga gas uap (PLTGU) di PT PJB Unit Pembangkitan Gresik. Sedangkan karakteristik individu dan lingkungan kerja yang meliputi usia, masa kerja, tingkat pemenuhan penggunaan APT (Alat pelindung Telinga), lama paparan kebisingan dan tingkat pajanan kebisingan merupakan faktor-faktor yang berpengaruh terhadap terjadinya perbedaan gangguan pendengaran akibat bising. Saran dan rekomendasi ditujukan kepada PT PJB Unit Pembangkitan Gresik agar dapat melakukan optimasi Program Konservasi Pendengaran (PKP) yang bertujuan untuk mencegah dan mengurangi tenaga kerja dari kerusakan atau kehilangan pendengaran akibat kebisingan di tempat kerja yang meliputi aktivitas-aktivitas diantaranya: mapping risk area sumber kebisingan, melakukan analisa kebisingan dengan menggunakan alat Sound Level Meter (SLM), melakukan kontrol kebisingan dengan berbagai cara peredaman bising, melakukan tes audiometri secara berkala, pemeliharaan catatan berkala (rekam medis operator central control room) dan penerapan penggunaan alat pelindung telinga (APT) pada area kerja dengan intensitas kebisingan melebihi NAB secara ketat. 


\section{DAFTAR PUSTAKA}

A.G. Adji, M. 2015. Info PJB: PJB Siap Sukseskan $35 G W$. Media Informasi dan Komunikasi PJB. Edisi 92.Februari 2015. Jakarta.

Rafika, A. 2012.Pengaruh Kebisingan terhadap Nilai Ambang Dengar Pada Pekerja Yang Terpapar Bising di PT PJB Unit Pembangkitan Gresik Studi Area PLTU 3 dan 4 PT PJB UP Gresik. Skripsi. Surabaya; Universitas Airlangga.

Bashiruddin, J. dan Soetirto, I. 2012. Gangguan Pendengaran Akibat Bising (Noise Induced Hearing Loss). Dalam Soepardi, E.A., Iskandar, N., Bashiruddin, J, dan RD. Restuti. Buku Ajar Ilmu Kesehatan Telinga, Hidung, Tenggorok, Kepala dan Leher. Edisi 5. Jakarta: Badan Penerbit FK UI. 42-45.

Dibyaguna, D.I. 2014. Faktor yang Berhubungan dengan Gangguan Pendengaran Pada Operator di PLTU PT PJB Unit Pembangkitan Gresik.Tugas Akhir. Surabaya; Universitas Airlangga.

Djojodibroto, Darmanto. 1999. Kesehatan Kerja di Perusahaan. Jakarta. Penerbit: PT Gramedia Pustaka Utama.

European Agency for Safety and Health at Work. 2008. Combined Exposures to Noise and Ototoxic Substance. European Risk Observatory Literature Review. Luxembourg: Office for Official Publications of The European Communities.

Harrington, JM. 2003. Buku Saku Kesehatan Kerja. Penerbit Buku Kedokteran, EGC: Dublin, Ohio.

Irwandi, R. 2008. Penyakit Akibat Kerja dan Penyakit Terkait Kerja. (online). Dari:http://library.usu. ac.id/download/ft/07002746.pdf(sitasi:2 Agustus 2015).

Notoatmodjo, S. 2012. Metodologi Penelitian Kesehatan. Jakarta: Rhineka Cipta.

Novita, S dan Yuwono, N. 2014. Diagnosis dan Tata Laksana Tuli Mendadak.(online). Dari: http://www. kalbemed.com/Portals/6/07_210Diagnosis\%20 dan $\% 20$ Tata $\% 20$ Laksana $\% 20$ Tu1i $\% 20$ Mendadak.pdf (sitasi 2 Agustus 2015).
Peraturan Menteri Tenaga Kerja dan Transmigrasi Nomor 13 Tahun 2011 tentang Nilai Ambang Batas Faktor Fisika dan Faktor Kimia di Tempat Kerja.

Prayogo, I. 2015. Analisis Perbedaan Gangguan Pendengaran (Auditori), Keluhan Subyektif Kelelahan Mata, dan Stres Kerja Studi Antara Operator Bergilir Central Control Room PLTU dan PLTGU di PT PJB Unit Pembangkitan Gresik. Skripsi. Surabaya: Universitas Airlangga.

PT. PLN (Persero). 2013. Statistik PLN 2013. Jakarta: Sekretariat Perusahaan PT PLN (Persero).

Sasongko.D.P., dkk. 2000. Kebisingan Lingkungan. Universitas Diponegoro: Semarang.

Soetirto, I. 1997."Tuli Akibat Bising (Noise Induced Hearing Loss)" dalam Buku Ajar Ilmu Penyakit Telinga Hidung Tenggorok Edisi Ketiga. Editor: H. Efiaty A. Soepardi, dokter, DSTHT dan Prof. H. Nurbaiti Iskandar, dokter, DSTHT, Penerbit: FKUI: Jakarta.

Suliyantoko, A dan Sutomo. 2009. Pengendalian Operasi PLTU dan PLTGU. Jakarta: Lintang Pancar Semesta.

Suma'mur, P.K. 2009. Higiene Perusahaan dan Kesehatan Kerja (Hiperkes). Sagung Seto: Jakarta.

Siswanto, A. 1998.Kebisingan. Surabaya: Balai Hiperkes dan Keselamatan Kerja Jawa Timur.

Tambunan, S.T.B. 2005.Kebisingan di Tempat Kerja (Occupational Noise). Andi: Yogyakarta.

Turmaningsih, S.P. 2010. Analisis Hubungan Umur dan Lama Pemajanan dengan Daya Dengar Berdasarkan Hasil Pemeriksaan Audiometri Tenaga Kerja di Unit Produksi Central Processing Area.

Job P-PEJ Tuban Jawa Timur. Skripsi. Surakarta: Fakultas Kedokteran Universitas Sebelas Maret. http://eprints.uns. ac.id/8129/1/144411308201009471.pdf(Diakses tanggal 3 Agustus 2015). 